\title{
Coral Diversity and the Severity of Disease Outbreaks: A Cross-Regional Comparison of Acropora White Syndrome in a Species-Rich Region (American Samoa) with a Species-Poor Region (Northwestern Hawaiian Islands)
}

\author{
G. S. Aeby, ${ }^{1}$ D. G. Bourne, ${ }^{2}$ B. Wilson, ${ }^{2}$ and T. M. Work ${ }^{3}$ \\ ${ }^{1}$ Hawaii Institute of Marine Biology, Kaneohe, HI 96744, USA \\ ${ }^{2}$ Australian Institute of Marine Science, PMB 3, Townsville, QLD 4810, Australia \\ ${ }^{3}$ US Geological Survey, National Wildlife Health Center, Honolulu Field Station, Honolulu, HI 96850, USA
}

Correspondence should be addressed to G. S. Aeby, greta@hawaii.edu

Received 16 July 2010; Accepted 27 November 2010

Academic Editor: Judith D. Lemus

Copyright ( $) 2011$ G. S. Aeby et al. This is an open access article distributed under the Creative Commons Attribution License, which permits unrestricted use, distribution, and reproduction in any medium, provided the original work is properly cited.

\begin{abstract}
The dynamics of the coral disease, Acropora white syndrome (AWS), was directly compared on reefs in the species-poor region of the Northwestern Hawaiian Islands (NWHI) and the species-rich region of American Samoa (AS) with results suggesting that biodiversity, which can affect the abundance of susceptible hosts, is important in influencing the impacts of coral disease outbreaks. The diversity-disease hypothesis predicts that decreased host species diversity should result in increased disease severity of specialist pathogens. We found that AWS was more prevalent and had a higher incidence within the NWHI as compared to AS. Individual Acropora colonies affected by AWS showed high mortality in both regions, but case fatality rate and disease severity was higher in the NWHI. The site within the NWHI had a monospecific stand of A. cytherea; a species that is highly susceptible to AWS. Once AWS entered the site, it spread easily amongst the abundant susceptible hosts. The site within AS contained numerous Acropora species, which differed in their apparent susceptibility to infection and disease severity, which in turn reduced disease spread. Manipulative studies showed AWS was transmissible through direct contact in three Acropora species. These results will help managers predict and respond to disease outbreaks.
\end{abstract}

\section{Introduction}

Ecosystem resilience can be defined as the capacity of a system to absorb disturbance and reorganize so as to retain the basic ecosystem services $[1,2]$. Regime shifts in ecosystems are increasingly common as a consequence of human activities that erode resilience. This is especially apparent for coral reefs worldwide, which are in decline primarily due to overharvesting, pollution, disease, and climate change [3-6]. Active and adaptive coral reef management is critical if we are to maintain these ecosystems, which requires an understanding of those processes that support coral reef resilience. A critical component underlying ecosystem resilience is the diversity of functional groups and their response to disturbance $[1,2]$. A functional group is a collection of species that perform a similar function, irrespective of their taxonomic affinities $[6,7]$. For example, herbivores such as reef fish and sea urchins, are an important functional group, which help to maintain the balance between corals and algae. Coral reefs that have high species diversity would have a higher capacity to absorb a disturbance since the loss of any one species could potentially be compensated for by the actions of others (functional redundancy). In the Caribbean, overfishing reduced the abundance of important fish herbivores, but this was initially compensated for by a corresponding increase in sea urchin populations [8-10]; when sea urchin populations subsequently collapsed from a disease outbreak [11], this led to massive losses of corals [12]. Resilience also requires variability in the response of the species within functional groups to the perturbation 
(response diversity) $[1,2]$. If all species respond in a similar manner then functional redundancy is lost. Coral reefs with a high diversity of species should therefore be more resilient to change, with a greater probability that some component of the species pool will be able withstand a specific stressor allowing for functional redundancy and response diversity.

The capacity of coral reefs to withstand the impacts of coral disease is of increasing concern. Coral disease has severely altered coral reefs in the Caribbean [13-17] and is increasing on reefs across the Indo-Pacific [18-25]. Models of global climate change predict that disease outbreaks, worldwide, will continue to increase through time [3, 4, 2628 ], and it is therefore important that managers are given sufficient information to predict how coral reefs may respond to future disease events in terms of their resistance and resilience. A basic premise of epidemiology is that increased host abundance enhances disease transmission, both initially into a population and subsequently within it, resulting in increased disease severity [29-31]. As such, the diversitydisease hypothesis predicts that low host species diversity can result in an increase in disease severity of specialist pathogens, since low host richness can, through relaxed interspecific competition, increase relative abundances of one or more susceptible hosts $[32,33]$. The diversity-disease hypothesis is well supported in plant-pathogen systems [3439] as well as some animal disease systems [40-43]. This hypothesis has not yet been adequately tested within the coral reef environment (but see [44]); however given examples from terrestrial ecosystems, coral reefs in species-rich regions should be more resistant and/or resilient to coral disease than reefs in species-poor regions. If so, then species diversity might be a good indicator for managers in predicting the outcome of disease events on reefs and an impetus for managing for species diversity. Within the Indo-Pacific, marine organisms exhibit a longitudinal biodiversity gradient with species-richness declining with increasing distance from the Indo-Australian Archipelago [45-47]. For example, over 500 coral species are found in the Indonesian-Philippines centre of diversity compared to less than 80 species within Hawaii $[48,49]$. Presumably, impacts of disease on coral reefs could be more severe in low diversity regions, especially for those diseases, which are more host specific such as Montipora white syndrome [50] or Acropora white syndrome [20], which have only been observed in the field affecting corals of a specific genus (e.g., Montipora and Acropora, respectively). However, little is known regarding the relationship between coral disease severity and coral species richness.

We present the first study to examine the role that biodiversity may play in influencing the impact of coral disease outbreaks, by comparing the dynamics of Acropora white syndrome (AWS) on a reef in a species-poor region (Northwestern Hawaiian Islands) (reef coral species $=80$ ) [49] with a reef in a species-rich region (American Samoa) (reef coral species $=276$ ) [51]. AWS is a coral disease that results in progressive tissue loss and which has caused extensive coral mortality in many regions throughout the Indo-Pacific $[19,20,22]$. AWS was first documented within the Northwestern Hawaiian Islands at French Frigate Shoals in 2003 [20] and studies on the disease were initiated in
2005. AWS was documented on Tutuila in American Samoa in 2004 [22] and in 2008 we conducted a parallel study on AWS dynamics. Our objectives were to (1) compare how differences in biological variables between the two regions influence the impact of disease events (e.g., the number of susceptible host species (species-richness), host, abundance (colony density and percent cover), and size class structure of the host coral; (2) document the initial AWS outbreak levels (prevalence) and subsequent disease spread (incidence) in each region; (3) compare the virulence (degree of colony mortality) of AWS on individual colonies between regions and among different host species; (4) determine whether AWS is transmissible and investigate any variation in transmissibility among host species.

\section{Methods}

2.1. Description of Sites. The Northwestern Hawaiian Islands (NWHI) are a chain of small rocky islands, atolls, coral islands, and reefs that span $1,800 \mathrm{~km}$ over more than five degrees of latitude in the northwestern portion of the Hawaiian Archipelago. The research site was located at French Frigate Shoals $\left(23^{\circ} 50^{\prime} \mathrm{N}, 166^{\circ} 10^{\prime} \mathrm{W}\right)$, which is a crescent-shaped atoll approximately $27 \mathrm{~km}$ in length with a well-formed barrier reef and lagoon [52]. The NWHI are now part of the Papahānaumokuākea Marine National Monument. The territory of American Samoa has a total land area of 76.1 square miles and includes five volcanic islands (Tutuila, Aunu'u, Ofu, Olosega, Ta'u) [53]. The research site was located in Vatia on the north side of Tutuila $\left(14^{\circ}\right.$ $\left.14^{\prime} \mathrm{S}, 170^{\circ} 40^{\prime} \mathrm{W}\right)$. These two regions were opportunistically chosen for comparison as each had reported outbreaks of AWS and were accessible for study.

2.2. Disease Prevalence and Incidence. Within each region, preliminary visual surveys were conducted to identify sites which were dominated by Acropora sp. and that had an ongoing AWS outbreak. When multiple outbreak sites were found, those sites having the highest AWS levels were chosen for the study. The Northwestern Hawaiian Islands was surveyed in May 2005 and resurveyed in May 2006. American Samoa was surveyed in June 2008 and was resurveyed in September 2009.

At each outbreak site, two $25 \mathrm{~m}$ transect lines were laid end-to-end and separated by approximately $3 \mathrm{~m}$. The substrate at the start of each transect (and every 5 meters thereafter) was marked with either a numbered cow tag or a steel pin ensuring that future surveys could be conducted over the same area on the reef. Coral colony density and size class structure were documented by recording Acropora colonies by size class along the transect lines. All Acropora sp., with a colony center within one meter on either side of the transect line $(25 \mathrm{~m} \times 2 \mathrm{~m})$, were enumerated and placed into one of seven size classes: $<5 \mathrm{~cm}, 5-10,10-20,20-40,40-80,80-160$, and $>160 \mathrm{~cm}$. These protocols have been used successfully in other studies to document size class structure within the NWHI [54-57]. Colonies were identified to species whenever possible. A second diver surveyed a wider area along the 


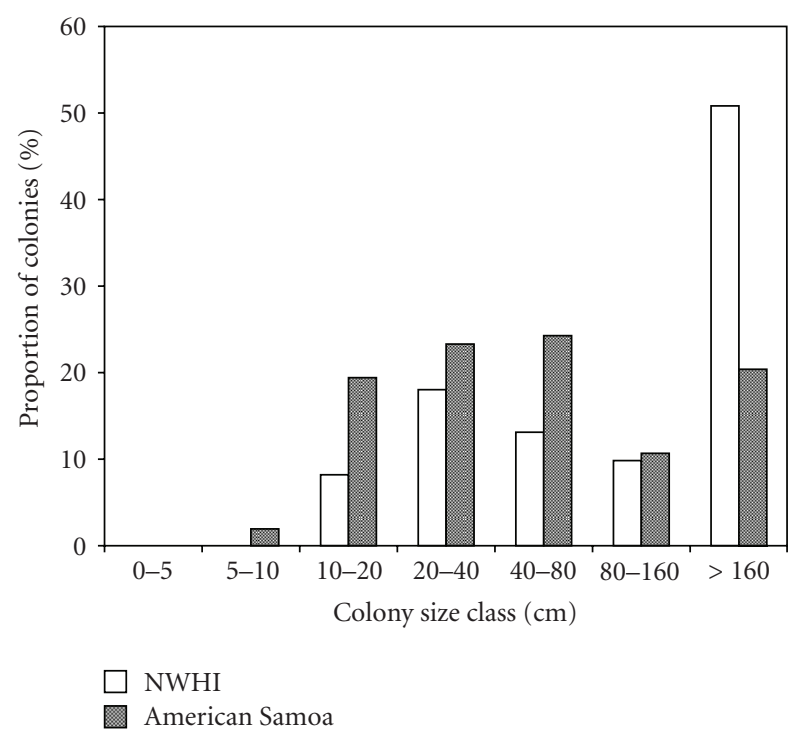

Figure 1: Mean size class structure of Acropora colonies within transects at the Acropora white syndrome outbreak sites in American Samoa and the northwestern Hawaiian Islands. Two $25 \times 2 \mathrm{~m}$ belt transects were surveyed at each site.

belt transect $(25 \mathrm{~m} \times 6 \mathrm{~m})$ for colonies exhibiting signs of AWS and measured coral cover using the point-intercept method, recording the substrate type at $50 \mathrm{~cm}$ intervals along the transect. Time constraints underwater prevented the enumeration of all coral colonies within the wider belt transects surveyed for disease. Therefore, we estimated the total number of colonies surveyed for disease based upon the mean number of colonies $\mathrm{m}^{-2}$ found within the narrower $(25$ $\times 2 \mathrm{~m}$ ) belt transects. Biological variables (average percent coral cover, colony density, and colony size class structure) and disease levels (number of AWS affected colonies and prevalence of AWS) were determined from diver surveys. To determine disease incidence (number of new cases), surveys were repeated one year later but it was not possible (poor weather and logistics) to reassess biological variables (\% coral and colony counts) in American Samoa and so only the number of new AWS colonies within the transects were enumerated.

2.3. AWS Virulence (Degree of Tissue Loss). To determine the progression of lesions, AWS-affected colonies that were initially identified within (or just outside) the belt transects, were tagged with either a colored cable tie or a numbered cow tag, photographed with a digital camera and the location on the reef mapped. The percentage of the colony surfaces that appeared diseased, healthy, or dead were scored in situ to provide a semiquantitative measure of AWS severity. Twenty infected colonies were tagged within the NWHI and 18 colonies were tagged in AS. The following year, the tagged colonies were relocated, photographed, and scored for tissue loss.

2.4. Differential Disease Susceptibility: Field Pattern and Transmissibility. Within AS, we determined whether there were differences in susceptibility to AWS among Acropora species, by examining disease prevalence among species and using a Chi-Square Goodness of Fit test to compare the abundance of each species within the transect (\% coral cover) with their respective contribution to total disease prevalence. Field patterns of AWS were indicative of a communicable agent, so manipulative experiments were conducted to test whether AWS is transmissible through direct contact or indirectly via the water column. We examined three Acropora species (A. cytherea, A. clathrata, and A. hyacinthus) to gather preliminary evidence as to whether there were differences in transmissibility among coral species. Experiments were conducted under static conditions using a paired design in which two aquaria (experimental and control) were used, with each aquarium containing two fragments of healthy Acropora sp. in $0.2 \mu \mathrm{m}$-filtered seawater. In the experimental tank, an infected fragment was placed in direct contact with one healthy fragment (direct transmission) and the other healthy fragment was placed $10 \mathrm{~cm}$ away (waterborne transmission). In control aquaria, a healthy fragment replaced the infected fragment, so as to control for lesions created by healthy coral-to-coral aggressive interactions. All fragments were examined daily for signs of acute tissue loss and photographed. Experiments were run until disease transmission occurred (tissue loss observed) on any of the fragments (touching or nontouching) or for a maximum of 8 days (time constraints). Water quality was maintained through daily partial water changes and each aquarium was aerated with a bubbler to simulate water motion. Aquaria were held under natural light and ambient temperatures (26$28^{\circ} \mathrm{C}$ ). A total of eight experimental replicates with controls were conducted: one run for $A$. clathrata, three runs for $A$. cytherea, and four runs for A. hyacinthus.

\section{Results}

3.1. Biological Variables and AWS Prevalence and Incidence. The site within the NWHI was dominated by a larger size class of Acropora colonies resulting in higher Acropora cover but lower colony density as compared to the AS site (Table 1; Figure 1). Only one species of Acropora (A. cytherea) was found at the site in the NWHI in contrast to the AS site in which at least six different Acropora species (A. cytherea, A. clathrata, A. abrotenoides, A. c.f. humilis, A. c.f. gemmifera, Acropora sp.) were identified. Both the initial prevalence and incidence (number of new cases) of AWS were higher in the NWHI relative to AS. Twenty-six AWS affected Acropora cytherea were initially identified within the NWHI survey area (prevalence $=14.2 \%$ ) as compared to 13 AWS colonies from at least 6 different species (A. cytherea, A. clathrata, A. abrotenoides, A. c.f. humilis, A. c.f. gemmifera, and Acropora sp.) in AS (prevalence $=4.2 \%$ ). In year two, 16 and four newly infected colonies were found in the NWHI and AS, respectively. This represents a $61.5 \%$ increase in disease in the NWHI and a $30.8 \%$ increase in AS.

3.2. AWS Virulence (Amount of Tissue Loss). In the NWHI, we were able to relocate 17 of the twenty marked colonies 


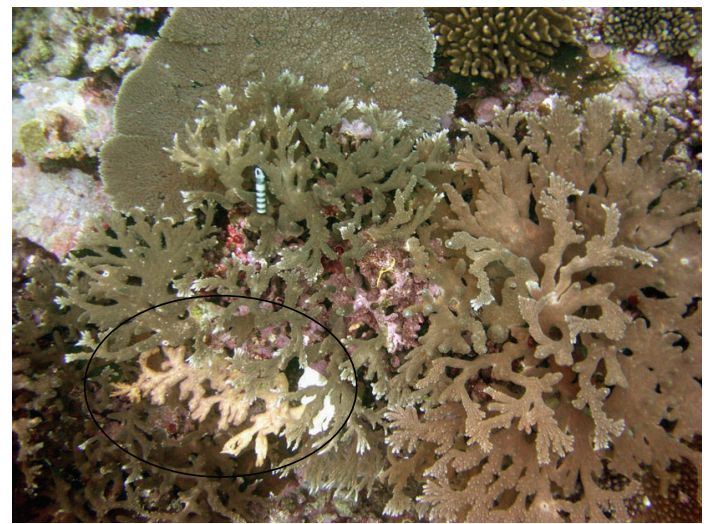

(a)

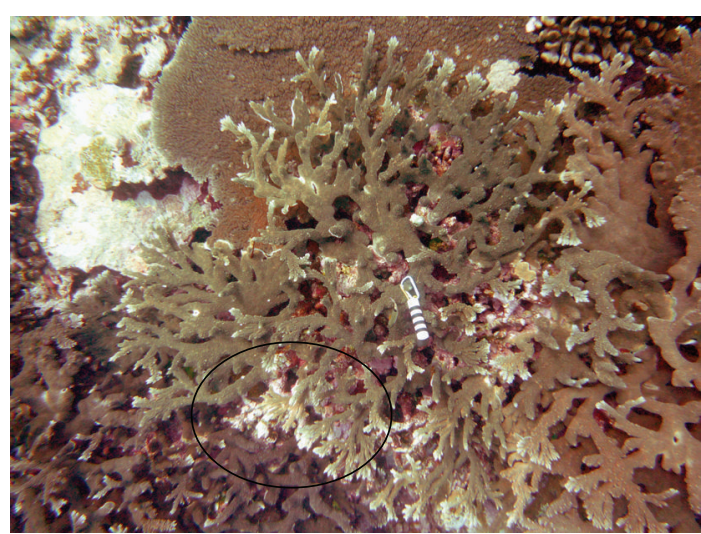

(b)

FIgURe 2: Example of minimal mortality from AWS in a resilient Acropora species (A. abrotenoides) in American Samoa. (a) A colony affected by AWS in 2008 and (b) shows the same colony in 2009; affected area circled.

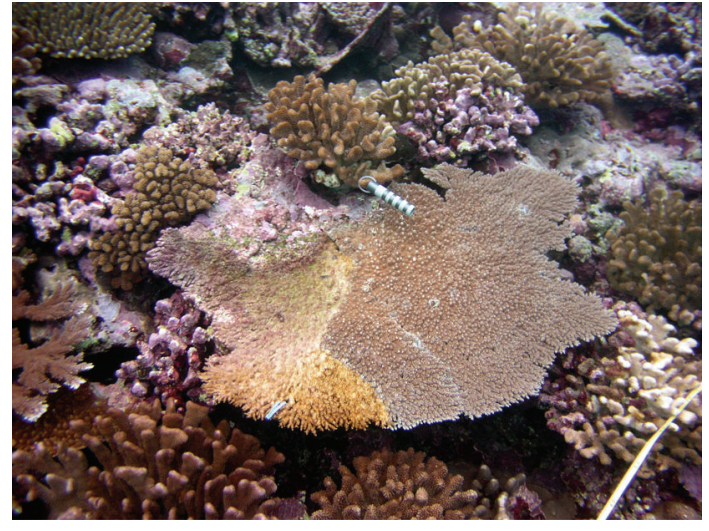

(a)

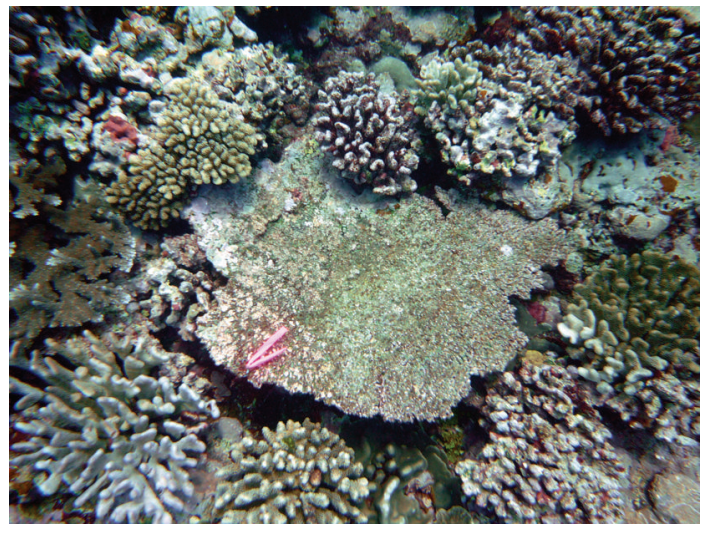

(b)

FIgURE 3: Example of complete mortality from AWS in a highly susceptible Acropora species (A. clathrata) in American Samoa. (a) The colony affected by AWS in 2008 and (b) shows the same colony in 2009.

TABLE 1: Differences in biological variables and disease levels and incidence at outbreak sites within the northwestern Hawaiian Islands (NWHI) and American Samoa (AS).

\begin{tabular}{lcc}
\hline Region & NWHI & AS \\
\hline depth $(\mathrm{m})$ & 9.1 & 9.1 \\
\# Acropora species within transects & 1 & $6+$ \\
Avg. Acropora cover $(\%)$ & 52.9 & 31.3 \\
Avg. Acropora density $\left(\# / \mathrm{m}^{2}\right)$ & 0.61 & 1.03 \\
est. \# Acropora colonies surveyed & 183 & 309 \\
Dominant colony size class within & $>160 \mathrm{~cm}$ & $40-80 \mathrm{~cm}$ \\
transects & 26 & 13 \\
\# AWS colonies year 0 & 16 & 4 \\
\# new AWS colonies year 1 & & \\
\hline
\end{tabular}

and all (100\%) showed signs of disease progression with the average increase in area of tissue loss on individual colonies being $46.2 \%$ ( $\mathrm{SE} \pm 5.5$ ). Within AS, 14 of the 18 marked colonies were relocated and the change in area of tissue loss ranged from $+15 \%$ (e.g., regrowth of tissue) (Figure 2) to $100 \%$ mortality (mean loss $=27.4 \% \mathrm{SE} \pm 8.9 \%$ ) (Figure 3 ). The initial severity ( $\%$ of colony dead or diseased) of the AWS-affected colonies was similar in both regions averaging $37.1 \%$ (SE $\pm 3.1 \%$ ) within the NWHI compared with $32 \%$ $(\mathrm{SE} \pm 7.7 \%)$ in AS. The mean disease severity increased in both regions after one year, indicating that the disease had progressed on individual colonies but mean severity was higher in the NWHI $(83.2 \% \mathrm{SE} \pm 6.2 \%)$ as compared to AS $(59.4 \% \mathrm{SE} \pm 12.4)$. Within the NWHI, case fatality rate was $58.8 \%$ with 10 out of 17 colonies showing $100 \%$ mortality. Within AS, 7 out of 14 colonies (A. clathrata, A. cytherea, and Acropora sp.) suffered $100 \%$ mortality (case fatality rate $=50 \%)$.

3.3. Differential Disease Susceptibility: Field Pattern and Transmissibility. At the site in AS, AWS prevalence varied among species but no clear relationship was found between AWS prevalence and differences in host abundance as measured by coral cover among affected species $\left(X^{2}=41.02\right.$, 


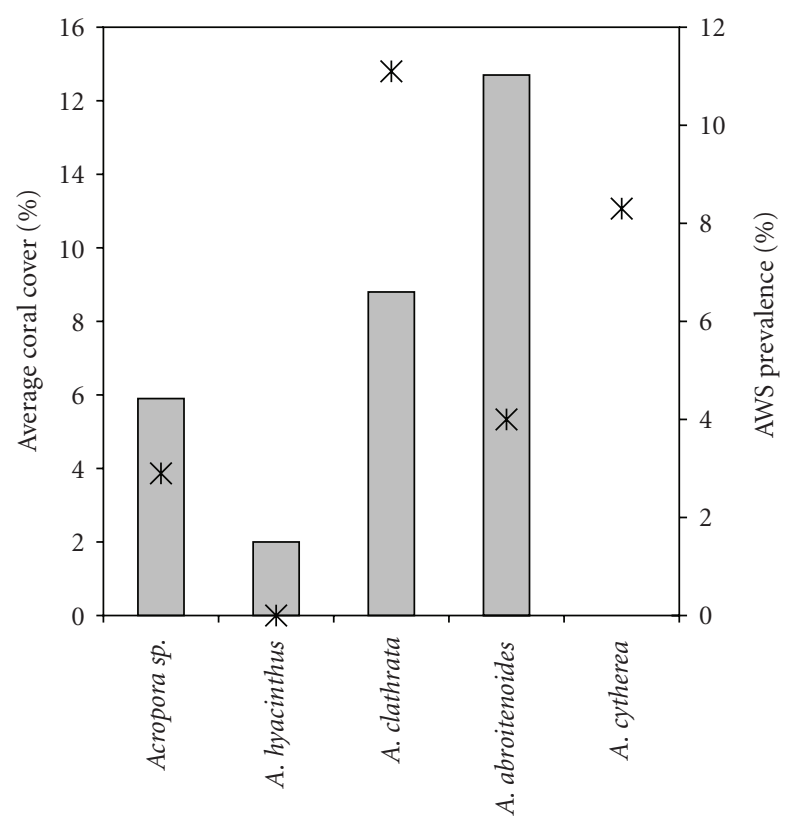

Coral species

Coral cover

* AWS prevalence

Figure 4: Differences in Acropora white syndrome prevalence among coral species and their respective average abundances within transects. Data are from the 2008 survey at the outbreak site within American Samoa. Note that colonies of $A$. cytherea, although present within the belt transect, did not occur directly underneath the transect line and so the percent of cover was measured as zero.

df $=3, P<.001$; Figure 4$)$. A. clathrata had the highest disease prevalence $(11.1 \%)$ but only comprised $8.8 \%$ of the coral cover. Similarly, A. cytherea had the second highest prevalence $(8.3 \%)$ yet made up $<1 \%$ of the coral cover. In contrast, $A$. abrotenoides had the highest contribution to coral cover $(14.7 \%)$ but only showed a $4 \%$ AWS prevalence. AWS was found to be transmissible through direct contact between AWS-affected and healthy coral fragments in six out of eight experimental runs $(75 \%)$. A. clathrata $(n=1)$ and $A$. cytherea $(n=3)$ demonstrated $100 \%$ successful direct transmission. Two of the four trials with A. hyacinthus resulted in disease transmission. Tissue loss was only observed in one fragment (A. cytherea) out of eight nontouching coral fragments within treatment aquaria. There were no signs of tissue loss recorded in any of the eight control aquaria. The time required for disease transmission to occur ranged from 1-4 days. Lesions appeared as acute tissue loss similar to that observed for AWS lesions in the field.

\section{Discussion}

Consistent with the diversity-disease hypothesis, this study found that an outbreak of AWS resulted in a greater degree of damage to the reef in the species-poor region of the
NWHI compared with the species-rich region of AS. The site within the NWHI had higher host abundance, which would facilitate disease transmission but specifically, the site was composed of a monospecific stand of large colonies of Acropora cytherea, a coral species that our study showed to be highly susceptible to AWS. Consequently, the incidence of disease within the NWHI was more severe than in AS initially and over time. The outbreak site in the NWHI also suffered greater coral mortality as evidenced by the higher case fatality rate and the greater amount of tissue loss (disease severity) on individual colonies.

The outbreak site within AS was also an Acroporarich area, but it contained at least six different species of Acropora. Disease prevalence varied among the coral species and these differences were not explained by host abundance. The branching coral Acropora abrotenoides appeared to be less susceptible to AWS with prevalence lower than would be expected based on the abundance of this species. $A$. abrotenoides was also resilient to the disease and the few colonies that were infected in 2008 were found to have suffered minimal colony mortality in 2009. In contrast, the plating corals, A. clathrata and A. cytherea, both showed extensive colony mortality from the disease and had a higher prevalence than would be expected based on their abundance on the reef suggesting that these species were especially vulnerable to AWS. Species-specific differences in disease susceptibility were also supported in aquaria studies examining the transmissibility of AWS. Although sample sizes were small and so must be interpreted with caution, we did find that AWS transmission was more successful in $A$. cytherea (three out of three trials) than with $A$. hyacinthus (two out of four trials). A similar pattern was observed in the field with A. hyacinthus occurring within the transects at the outbreak site but no colonies were infected with AWS. Numerous studies have found differences in disease susceptibility among coral genera and Acropora sp. are emerging as one of the most vulnerable coral genera to diseases $[19,22,58]$. This study reveals that differential disease susceptibility can also occur between species within a genus.

Although the dynamics of disease etiology are complex and can be affected by a number of factors, our study suggests that species-richness may be important in determining the extent of damage occurring on a coral reef due to disease. We found that differential disease susceptibility among Acropora species (response diversity) in AS-reduced disease spread and virulence. Susceptible species formed a smaller component of the AS ecosystem, decreasing successful disease transmission and thereby minimizing damage from the disease outbreak. The underlying process is a function of host abundance and indeed several studies have demonstrated a positive relationship between coral abundance and disease prevalence $[23,50,59,60]$. However, it must also be noted that we were comparing disease outbreaks between regions during different years and so other factors could have also affected disease outcomes. For example, thermal stress has been found to affect coral disease processes $[4,59]$ and if temperatures had varied between the two study years more so in one region than 
the other then that might explain differences in disease spread. However, the SST did not vary much between the two years of the studies in either region (http://coralreefwatch.noaa.gov/satellite/current/sst_series_24reefs.html). Disease outbreaks in populations of susceptible hosts can often be more severe early on when host density is highest [29-31] and so timing of the initial disease outbreak might have contributed to the differences found between AS and NWHI. We know that the outbreak in the NWHI occurred at the study site in 2003, as it is one of our monitoring sites [20]. Therefore, we know that the disease had been ongoing for 2 years when our study was initiated in 2005. The AS site was not a monitoring site and so we do not know when AWS first appeared. However, our surveys found little evidence of past coral mortality such as would be expected from a prior disease event suggesting that AWS had recently emerged. Based on these observations, a more rapid disease spread would have been expected in AS rather than the NWHI. Hence, regardless of other potential cofactors, the interspecific variability in susceptibility to AWS found in AS still offers the most reasonable explanation for the differences we observed in AWS virulence and spread among regions.

The relationship between species diversity and disease severity may not be valid for diseases that affect multiple host genera. For example, Ward et al. [44] examined the diversity-disease hypothesis on coral reefs along the Mexican Yucatan Peninsula and found no relationship between disease prevalence and measures of host diversity. However, they included many diseases found to affect multiple host genera, such as black band disease which is known to affect 19 Caribbean shallow-water coral species and 45 IndoPacific coral species [17]. For coral diseases with low host specificity, a negative relationship between species-richness and abundance of susceptible hosts would no longer apply since multiple species or genera can be affected by disease.

For managers, this information is essential for predicting and responding to diseases outbreaks. It is of utmost importance that reef managers know the species-richness and community composition of those coral reefs under their jurisdiction and are aware of which coral diseases might affect their reefs, host susceptibility and have insight into the ecology underlying those diseases (etiology, mode of transmission, etc). Support of research to understand local coral disease processes should be encouraged, and in speciespoor regions, such as the Northwestern Hawaiian Islands, a proactive approach is required to develop the capacity to respond to disease outbreaks rapidly and efficiently as disease outbreaks are likely to result in high mortality. Most critical is research in understanding disease causation in corals, since only through understanding this aspect can diseases be effectively managed.

Disease management in other wildlife systems is routinely used and include actions such as culling, vaccination, or habitat alteration which minimize the spread of disease and the resulting mortality [61]. A recent example of this was management of avian botulism in endangered Laysan ducks in the NWHI by draining affected ponds thereby reducing the amount of bacteria in the environment that causes botulism [62]. For coral disease, much less is known about the causes or ecology of the diseases and so the development of management actions is far more difficult [63]. However, some coral disease management has been successfully implemented. For example, in the Florida Keys, Hudson [64] treated black band disease (70\% effective) by removing the pathogen by suction and covering the affected area with modeling clay (lesion occlusion). In Australia, Dalton et al. [65] found that mechanical removal of the advancing disease margin for Turbinaria colonies affected by a tissue loss disease ("white syndrome") was successful at halting the disease in $80 \%$ of the colonies. AWS might be effectively managed by either lesion occlusion or mechanical removal of affected parts depending on the severity of the disease on the colony and the colony morphology. Although information regarding the treatment of coral diseases is still limited, these two studies show that disease management can be accomplished in the marine environment. Further work should be encouraged in developing methods to manage coral disease as we also continue to understand disease processes.

Coral disease is a very real threat to global reefs. The findings in this study show that reefs in species-rich regions might be more resistant and resilient to those coral diseases, such as Acropora white syndrome, that are more host specific (genus level). More detailed studies are required to unravel the complex interaction of variables that affect disease dynamics, such that adequate and timely management actions can be taken to maintain these valuable coral reef ecosystems. Cross-regional comparisons, such as this one, are also of great value, so we might better understand the spread of disease across the Indo-Pacific and in identifying general patterns of disease dynamics on these reefs.

\section{Acknowledgments}

The authors gratefully acknowledge the American Samoa Department of Marine and Wildlife Resources and American Samoa National Park Service for guidance in development of the study and with logistical support. They thank also the Captain and crew of the NOAA ship Hi'ialakai for logistical support within the Northwestern Hawaiian Islands. Funding for this research came from NOAA's Coral Reef Conservation grant through the Hawaii Undersea Research Lab and the Papahānaumokuākea Marine National Monument-Hawaii Institute of Marine Biology MOA. This paper was greatly improved by two anonymous reviewers.

\section{References}

[1] T. Elmqvist, C. Folke, M. Nystrom et al., "Response diversity, ecosystem change and resilience," Frontiers in Ecology and the Environment, vol. 1, no. 9, pp. 488-494, 2003.

[2] C. Folke, S. Carpenter, B. Walker et al., "Regime shifts, resilience, and biodiversity in ecosystem management," Annual Review of Ecology, Evolution, and Systematics, vol. 35, pp. 557-581, 2004.

[3] C. D. Harvell, K. Kim, J. M. Burkholder et al., "Emerging marine diseases-climate links and anthropogenic factors," Science, vol. 285, no. 5433, pp. 1505-1510, 1999. 
[4] C. D. Harvell, E. Jordan-Dahlgren, S. Merkel et al., "Coral disease, environmental drivers, and the balance between coral and microbial associates," Oceanography, vol. 20, no. 1, pp. 58 81, 2007.

[5] T. P. Hughes, A. H. Baird, D. R. Bellwood et al., "Climate change, human impacts, and the resilience of coral reefs," Science, vol. 301, no. 5635, pp. 929-933, 2003.

[6] D. R. Bellwood, T. P. Hughes, C. Folke, and M. Nyström, "Confronting the coral reef crisis," Nature, vol. 429, no. 6994, pp. 827-833, 2004.

[7] R. S. Steneck and M. N. Dethier, "A functional group approach to the structure of algal-dominated communities," Oikos, vol. 69, no. 3, pp. 476-498, 1994.

[8] J. C. Ogden, R. A. Brown, and N. Salesky, "Grazing by the echinoid Diadema antillarum Philippi: formation of halos around West Indian patch reefs," Science, vol. 182, no. 4113, pp. 715-717, 1973.

[9] M. E. Hay, "Patterns of fish and urchin grazing on Caribbean coral reefs: are previous results typical?" Ecology, vol. 65, no. 2, pp. 446-454, 1984.

[10] T. P. Hughes, "Catastrophes, phase shifts, and large-scale degradation of a Caribbean coral reef," Science, vol. 265, no. 5178, pp. 1547-1551, 1994.

[11] H. A. Lessios, D. R. Robertson, and J. D. Cubit, "Spread of Diadema mass mortality through the Caribbean," Science, vol. 226, no. 4672, pp. 335-337, 1984.

[12] H. A. Lessios, "Mass mortality of Diadema antillarum in the Caribbean: what have we learned?" Annual Review of Ecology and Systematics9, vol. 19, pp. 371-393, 1988.

[13] W. Gladfelter, "White-band disease in Acropora palmata: implications for the structure and growth of shallow reefs," Bulletin of Marine Science, vol. 32, pp. 639-643, 1982.

[14] J. W. Porter, P. Dustan, W. C. Jaap et al., "Patterns of spread of coral disease in the Florida Keys," Hydrobiologia, vol. 460, pp. $1-24,2001$.

[15] D. L. Santavy, E. Mueller, E. C. Peters et al., "Quantitative assessment of coral diseases in the Florida Keys: strategy and methodology," Hydrobiologia, vol. 460, pp. 39-52, 2001.

[16] K. L. Patterson, J. W. Porter, K. B. Ritchie et al., "The etiology of white pox, a lethal disease of the Caribbean elkhorn coral, Acropora palmata," Proceedings of the National Academy of Sciences of the United States of America, vol. 99, no. 13, pp. 8725-8730, 2002.

[17] K. P. Sutherland, J. W. Porter, and C. Torres, "Disease and immunity in Caribbean and Indo-Pacific zooxanthellate corals," Marine Ecology Progress Series, vol. 266, pp. 273-302, 2004.

[18] L. J. H. Raymundo, C. D. Harvell, and T. L. Reynolds, "Porites ulcerative white spot disease: description, prevalence, and host range of a new coral disease affecting Indo-Pacific reefs," Diseases of Aquatic Organisms, vol. 56, no. 2, pp. 95-104, 2003.

[19] B. Willis, C. Page, and E. Dinsdale, "Coral disease on the great barrier reefs," in Coral Health and Disease, E. Rosenberg and Y. Loya, Eds., pp. 69-104, Springer, Berlin, Germany, 2004.

[20] G. S. Aeby, "Outbreak of coral disease in the Northwestern Hawaiian Islands," Coral Reefs, vol. 24, no. 3, p. 481, 2005.

[21] G. J. Williams, G. S. Aeby, and S. K. Davy, "Coral disease at Palmyra Atoll, a remote reef system in the Central Pacific," Coral Reefs, vol. 27, no. 1, p. 207, 2008.

[22] G. Aeby, T. Work, D. Fenner, and E. di Donato, "oral and crustose coralline algae disease on the reefs of American Samoa," in Proceedings of the 11th International Coral Reef Symposium, pp. 197-201, 2009.
[23] R. L. Myers and L. J. Raymundo, "Coral disease in Micronesian reefs: a link between disease prevalence and host abundance," Diseases of Aquatic Organisms, vol. 87, no. 1-2, pp. 97-104, 2009.

[24] M. Sussman, B. L. Willis, S. Victor, and D. G. Bourne, "Coral pathogens identified for White Syndrome (WS) epizootics in the Indo-Pacific," PLoS ONE, vol. 3, no. 6, Article ID e2393, 2008.

[25] B. Vargas-Ángel, "Coral health and disease assessment in the U.S. pacific remote ISLAND areas," Bulletin of Marine Science, vol. 84, no. 2, pp. 211-227, 2009.

[26] E. Rosenberg and Y. Ben-Haim, "Microbial diseases of corals and global warming," Environmental Microbiology, vol. 4, no. 6, pp. 318-326, 2002.

[27] S. Sokolow, "Effects of a changing climate on the dynamics of coral infectious disease: a review of the evidence," Diseases of Aquatic Organisms, vol. 87, no. 1-2, pp. 5-18, 2009.

[28] M. E. Mouchka, I. Hewson, and C. D. Harvell, "Coralassociated bacterial assemblages: current knowledge and the potential for climate-driven impacts," Integrative and Comparative Biology, vol. 50, no. 4, pp. 662-674, 2010.

[29] R. M. Anderson and R. M. May, "Population biology of infectious diseases: part I," Nature, vol. 280, no. 5721, pp. 361367, 1979.

[30] J. Antonovics, Y. Iwasa, and M. P. Hassell, "A generalized model of parasitoid, venereal, and vector-based transmission processes," American Naturalist, vol. 145, no. 5, pp. 661-675, 1995.

[31] C. E. Mitchell, D. Tilman, and J. V. Groth, "Effects of grassland plant species diversity, abundance, and composition on foliar fungal disease," Ecology, vol. 83, no. 6, pp. 1713-1726, 2002.

[32] C. Elton, The Ecology of Invasions by Animals and Plants, John Wiley \& Sons, New York, NY, USA, 1958.

[33] J. van der Plank, Plant Diseases: Epidemics and Control, Academic Press, New York, NY, USA, 1963.

[34] M. Wolfe, "The current status and prospects of multiline cultivars and variety mixtures for disease resistance," Annual Review of Phytopathology, vol. 23, pp. 251-273, 1985.

[35] P. J. Burton, A. C. Balisky, L. P. Coward, S. G. Cumming, and D. D. Kneeshaw, "The value of managing for biodiversity," Forestry Chronicle, vol. 68, no. 2, pp. 225-237, 1992.

[36] G. S. Gilbert and S. P. Hubbell, "Plant diseases and the conservation of tropical forests," BioScience, vol. 46, no. 2, pp. 98-106, 1996.

[37] M. Bourdreau and C. Mundt, "Ecological approaches to disease control," in Environmentally Safe Approaches to Crop Disease Control, N. Rechcigl and J. Rechcigl, Eds., pp. 33-62, CRC Press, Boca Raton, Fla, USA, 1997.

[38] M. Finckh and M. Wolfe, "The use of biodiversity to restrict plant diseases and some consequences for farmers and society," in Ecology in Agriculture, J. Jackson, Ed., pp. 203-237, Academic Press, San Diego, Calif, USA, 1997.

[39] K. A. Garrett and C. C. Mundt, "Epidemiology in mixed host populations," Phytopathology, vol. 89, no. 11, pp. 984-990, 1999.

[40] R. S. Ostfeld and F. Keesing, "Biodiversity and disease risk: the case of Lyme disease," Conservation Biology, vol. 14, no. 3, pp. 722-728, 2000.

[41] K. LoGiudice, R. S. Ostfeld, K. A. Schmidt, and F. Keesing, "The ecology of infectious disease: effects of host diversity and community composition on lyme disease risk," Proceedings of the National Academy of Sciences of the United States of America, vol. 100, no. 2, pp. 567-571, 2003. 
[42] J. P. Swaddle and S. E. Calos, "Increased avian diversity is associated with lower incidence of human West Nile infection: observation of the dilution effect," PLoS ONE, vol. 3, no. 6, Article ID e2488, 2008.

[43] F. Altermatt and D. Ebert, "Genetic diversity of Daphnia magna populations enhances resistance to parasites," Ecology Letters, vol. 11, no. 9, pp. 918-928, 2008.

[44] J. R. Ward, K. L. Rypien, J. F. Bruno et al., "Coral diversity and disease in Mexico," Diseases of Aquatic Organisms, vol. 69, no. 1, pp. 23-31, 2006.

[45] F. Stehli and J. W. Wells, "Diversity and age patterns in hermatypic coral," Systematic Biology, vol. 20, pp. 115-126, 1971.

[46] J. E. N. Veron, Corals in Space and Time: The Biogeography and Evolution of the Scleractinia, UNSW Press, Sydney, Australia, 1995.

[47] D. R. Bellwood and T. P. Hughes, "Regional-scale assembly rules and biodiversity of coral reefs," Science, vol. 292, no. 5521, pp. 1532-1534, 2001.

[48] J. E. N. Veron, Corals of the World, AIMS, Townsville, Australia, 2000.

[49] A. Friedlander, G. Aeby, S. Balwani et al., "The state of coral reef ecosystems of the northwestern Hawaiian Islands," in The State of Coral Reef Ecosystems of the United States and Pacific Freely Associated States, J. Waddell, Ed., pp. 263306, NOAA/NCCOS Center for Coastal Monitoring and Assessment's Biogeography Team, Silver Spring, Md, USA, 2008.

[50] G. S. Aeby, M. Ross, G. J. Williams, T. D. Lewis, and T. M. Work, "Disease dynamics of Montipora white syndrome within Kaneohe Bay, Oahu, Hawaii: distribution, seasonality, virulence, and transmissibility," Diseases of Aquatic Organisms, vol. 91, no. 1, pp. 1-8, 2010.

[51] D. Fenner, M. Speicher, S. Gulick et al., "The state of coral reef ecosystems American Samoa," in The State of Coral Reef Ecosystems of the United States and Pacific Freely Associated States, J. Waddell, Ed., pp. 307-351, NOAA/NCCOS Center for Coastal Monitoring and Assessment's Biogeography Team, Silver Spring, Md, USA, 2008.

[52] NOAA (National Oceanic and Atmospheric Administration), Atlas of the Shallow-Water Benthic Habitats of the Northwestern Hawaiian Islands, NOAA, Silver Spring, Md, USA, 2003.

[53] P. Craig, Natural History Guide to American Samoa, National Park of American Samoa, Pago Pago, American Samoa, USA, 2002.

[54] J. E. Maragos, D. C. Potts, G. Aeby et al., "The 2000-2002 rapid ecological assessment of corals in the Northwestern Hawaiian Islands. Part I. Species and distribution," Pacific Science, vol. 58, no. 2, pp. 211-230, 2004.

[55] J. C. Kenyon, P. S. Vroom, K. N. Page, M. J. Dunlap, C. B. Wilkinson, and G. S. Aeby, "Community structure of hermatypic corals at French Frigate Shoals, Northwestern Hawaiian Islands: capacity for resistance and resilience to selective stressors," Pacific Science, vol. 60, no. 2, pp. 153-175, 2006.

[56] J. C. Kenyon, C. B. Wilkinson, M. J. Dunlap, G. S. Aeby, and C. Kryss, "Community structure of hermatypic corals at Laysan and Lisianski/Neva Shoal, Northwestern Hawaiian Islands: a new layer of scientific exploration," Atoll Research Bulletin, no. 550, pp. 1-28, 2007.

[57] J. C. Kenyon, C. B. Wilkinson, and G. S. Aeby, "Community structure of hermatypic corals at maro reef in the north- western hawaiian islands: a unique open atoll," Atoll Research Bulletin, no. 558, pp. 1-24, 2008.

[58] G. S. Aeby, "Baseline levels of coral disease in the Northwestern Hawaiian Islands," Atoll Research Bulletin, no. 543, pp. 471488, 2006.

[59] J. F. Bruno, E. R. Selig, K. S. Casey et al., "Thermal stress and coral cover as drivers of coral disease outbreaks," PLoS ONE, vol. 5, no. 6, pp. 1-8, 2007.

[60] J. Haapkylä, R. K. F. Unsworth, A. S. Seymour et al., "Spatiotemporal coral disease dynamics in the Wakatobi Marine National Park, South-East Sulawesi, Indonesia," Diseases of Aquatic Organisms, vol. 87, no. 1-2, pp. 105-115, 2009.

[61] M. Friend and J. C. Franson, "Field manual of wildlife diseases: general field procedures and diseases of birds," Information and Technology Report 1999-01, USGS, 1999.

[62] T. M. Work, J. L. Klavitter, M. H. Reynolds, and D. Blehert, "Avian botulism: a case study in translocated endangered laysan ducks (Anas laysanensis) on midway atoll," Journal of Wildlife Diseases, vol. 46, no. 2, pp. 499-506, 2010.

[63] T. M. Work, L. L. Richardson, T. L. Reynolds, and B. L. Willis, "Biomedical and veterinary science can increase our understanding of coral disease," Journal of Experimental Marine Biology and Ecology, vol. 362, no. 2, pp. 63-70, 2008.

[64] H. Hudson, " First aid for massive corals infected with black band disease, Phormidium corallyticum: an underwater aspirator and post-treatment sealant to curtail re-infection," in Diving for Science in the 21st Century: Proceedings of the 20th Annual Scientific Diving Symposium, Hallock and French, Eds., American Academy of Underwater Sciences, St Pete Beach, Fla, USA, 2000.

[65] S. J. Dalton, S. Godwin, S. D. A. Smith, and L. Pereg, "Australian subtropical white syndrome: a transmissible, temperature-dependent coral disease," Marine and Freshwater Research, vol. 61, no. 3, pp. 342-350, 2010. 

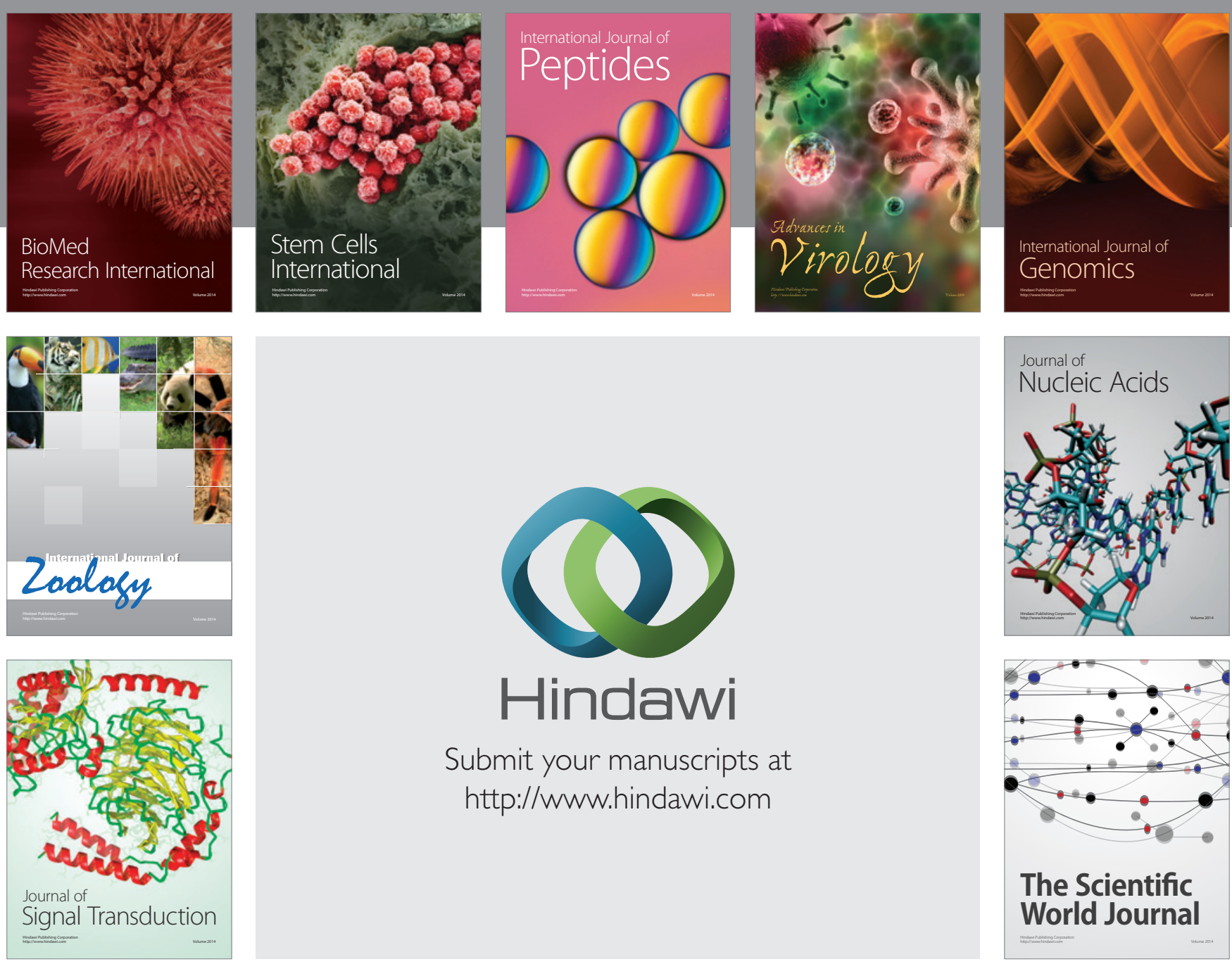

Submit your manuscripts at

http://www.hindawi.com
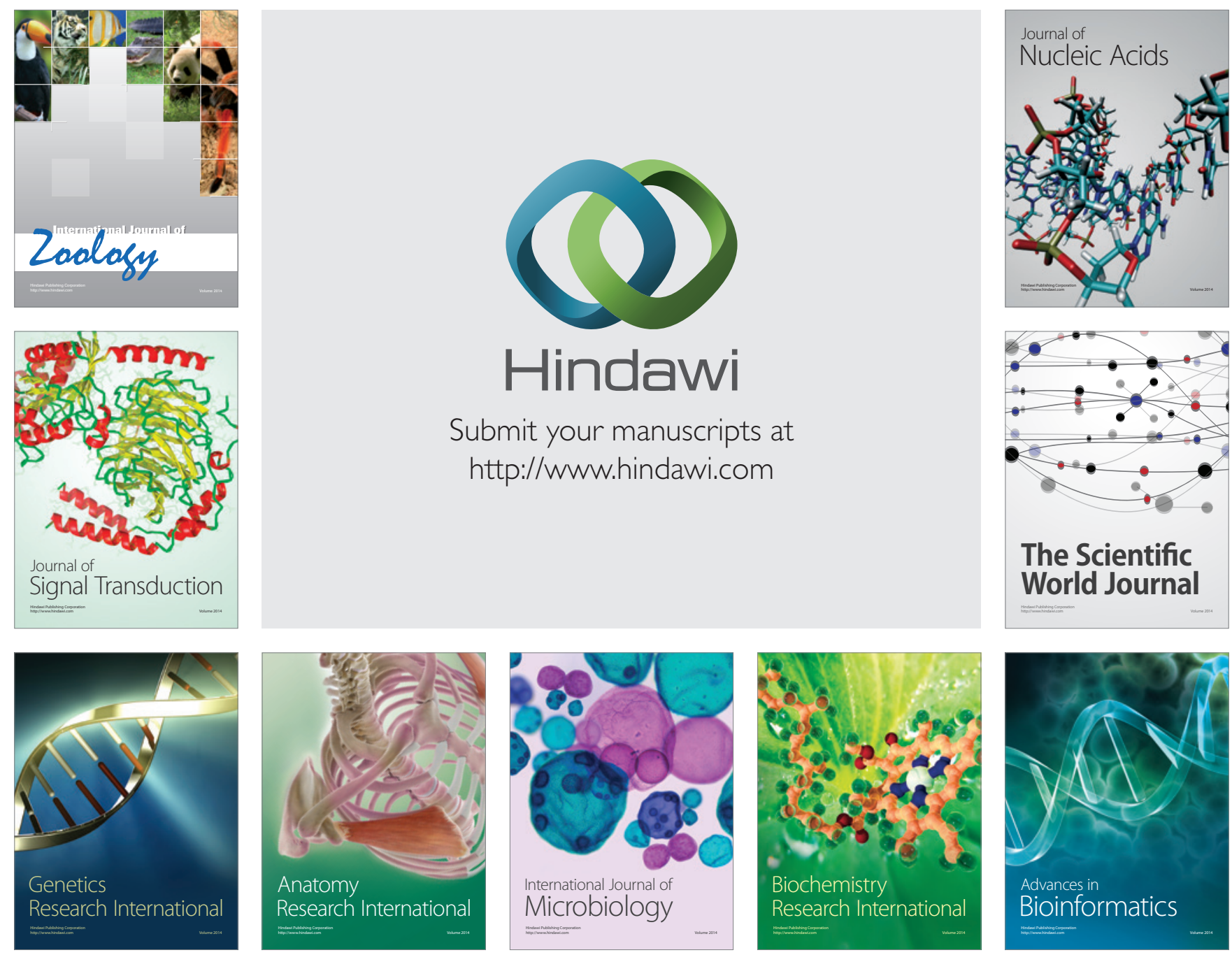

The Scientific World Journal
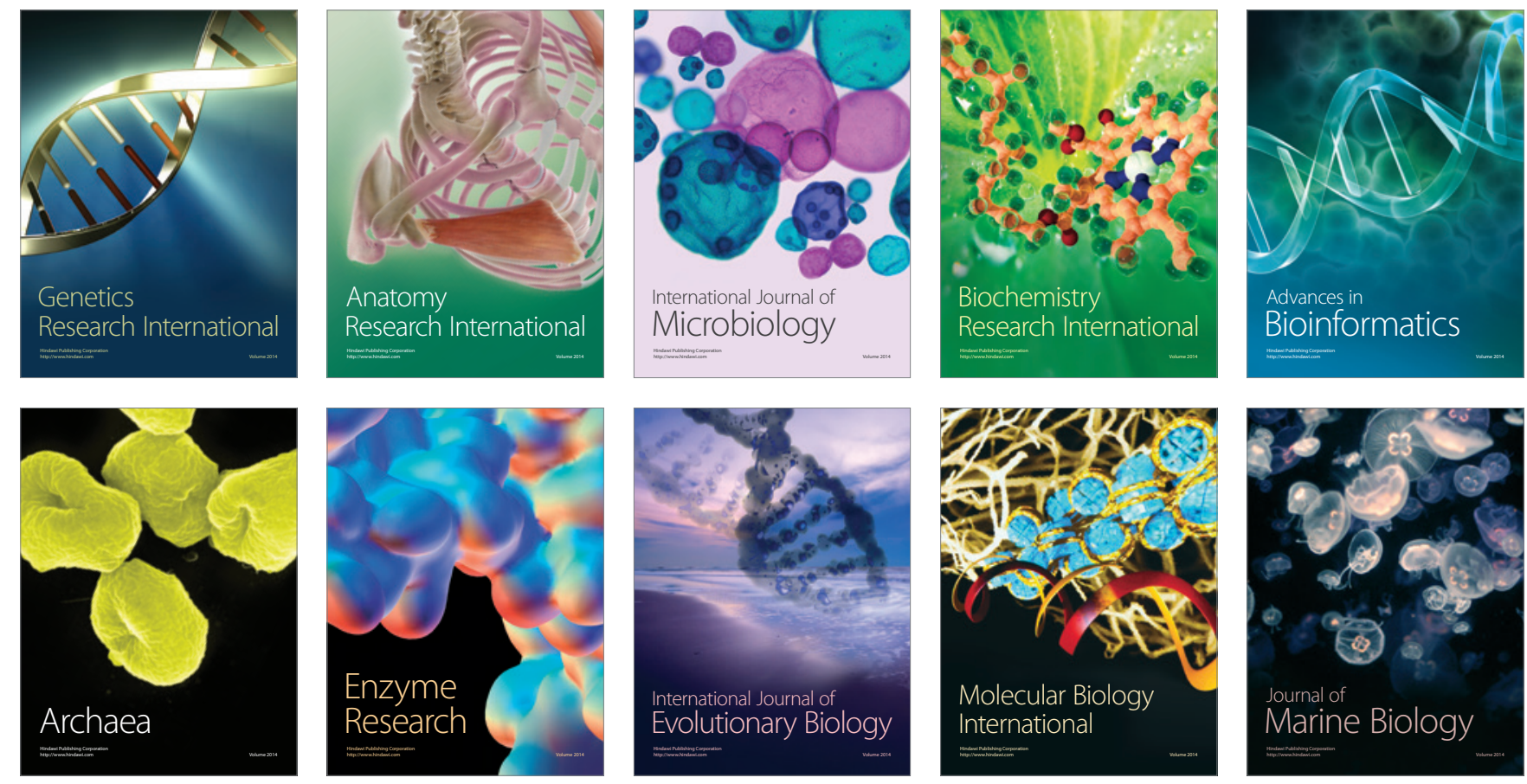